The version of the article accepted for publication in the Journal of Consumer Culture

Joanna Zalewska

The Maria Grzegorzewska Academy of Special Education, Poland

\title{
Consumer revolution in People's Poland: Technologies in everyday life and the negotiation between custom and fashion (1945-1980)
}

\begin{abstract}
Drawing upon ethnographic data, this article discusses the adoption of technologies into everyday life in People's Poland, in the wider theoretical context of the consumer revolution or a shift in consumption patterns towards fashion. There were two mechanisms of the consumer revolution in People's Poland: collective usefulness and modern hedonism. For the mechanism of collective usefulness, the main factors in the shift in consumption patterns were the state-controlled propaganda of 'progress' and the domestication of technology. Household appliances were adopted as necessities that helped people fulfil their needs, in line with the idea of 'progress' propagated by the authorities of People's Poland in the post-war period. In the process of the domestication of technology, customarily female activities were changing into flexible practices of using household appliances driven by fashion. In the case of modern hedonism, the main factor in the shift towards fashion was the 'advertising' of a Western standard of living in American films shown on television in the 1960s. The course of the consumer revolution was diversified by gender, social class and generation.
\end{abstract}

Keywords: Consumption, consumer revolution, fashion, custom, domestication of technology, technologies, idea of progress, Poland, modern hedonism, everyday life

The domestication of technology in Western countries is widely discussed in the

literature (Cowan, 1976; Hand and Shove, 2004, 2007; Silverstone, 1993). However,

there is a significant lack of analyses related to Eastern European countries from the

former Soviet bloc. Drawing on ethnographic research conducted in Warsaw, this article 
discusses the implementation of mass technologies in daily life in Poland during the period between the end of the Second World War and the beginning of the 1980s. This period involved significant changes to everyday practices associated with the adoption of technologies in daily life (Zalewska, 2011). This article is concerned with the specific process by which mass technologies were implemented in everyday Polish life and the significance of this case to broader theoretical understandings of the consumer revolution. The adoption of innovations was associated with a wider process of withdrawing from the natural economy to develop the state market, enhancing the participation of households in the money economy, and increasing expenditures on industrial goods, or an economic consumer revolution (McKendrick, Brewer and Plumb, 1982). The other side of economic changes involved social changes concerning consumption patterns. In sociological terms, the consumer revolution can be understood as a generalised shift in socially organised patterns of consumption away from regulation by interdiction or sumptuary law over particular social categories and towards fashion governing consumption through social emulation (Appadurai, 1996). In this broad sense, the consumer revolution occurred in different periods for different sections of Western societies, reaching a level of mass consumption at the beginning of the twentieth century in the US (Aldridge, 2003) and after the Second World War in Western Europe (de Grazia, 2005). 
After the Second World War, Poland came under the Soviet Union's hegemony and adopted a socialistic system. In the People's Republic of Poland (the so-called People's Poland), the shift in socially organised patterns of consumption towards fashion was inhibited, on the one hand, by customary norms that were deeply rooted in a society in which $70 \%$ of the population lived in relatively poor and economically underdeveloped traditional peasant communities before the war. On the other hand, an obstacle was posed by the indolence of the public sphere of People's Poland (GizaPoleszczuk, 2002). The government's investment in the consumer goods sector was insufficient, which resulted in shortages. A common feature of the countries from the Soviet bloc was the so-called shortage economy (Kornai, 1992). The analysis of the Polish case outlined here suggests an alternative scenario of the consumer revolution and stresses the role of distinct factors at work: namely, the state-controlled socialist propaganda of progress and the adoption of domestic technologies.

Technological innovations began to enter daily life in Poland after the Second World War. The socialist authorities of People's Poland implemented new facilities, such as connections to the electrical grid and water, sewage, and gas networks in housing construction. The authorities conducted a propaganda campaign of progress to encourage the adoption of technology, and they fought illiteracy. These activities provided a foundation that facilitated the adoption of technology. 'Frania' upright rotary 
washing machines, named after the most popular model, were produced in local factories beginning in the 1950s and became widespread in the 1960s, as did refrigerators at the turn of the 1960s and 1970s (Szpakowska, 2008). News from the West, disseminated primarily through television, contributed to the interest in technological innovations. Throughout the 1960s, the prevalence of television watching increased significantly (Kurz, 2008). Television 'advertised' the consumer goods shown in American films. Alan Warde argues that consumption is 'a moment in almost every practice' (2005: 137), understood as an 'embodied, materially mediated array of human activity centrally organized around shared practical understanding' (Schatzki, 2001: 11). For instance, 'cars are worn out and petrol is burned in the process of motoring' (Warde, 2005: 137). The Poles observed American practices on television. The average Pole wanted to look and live like the people on the other side of the screen (Pleskot, 2007). Desire appears to have been connected with the possibility of participating in the practices and experiencing the emotions evoked by the practices rather than the goods themselves (Campbell, 1987). This awakened consumer desire was not addressed on a wider scale until the 1970s, when the authorities imported Western technologies to apply them in industrial production. At this time, automatic washing machines and cars such as the Fiat 125p and Fiat 126p entered the market.

In this article, I will describe how new practices and networks of humans and 
non-humans (Latour, 2005) were created through the incorporation of technologies into everyday life. I will discuss the role of the domestication of technologies in the shift in consumption patterns towards fashion. The concept of the 'interpretative flexibility' of technology (Wajcman, 2000) suggests that this process was complex. Fashion was bound to be simultaneously adopted and resisted, and the relationships between innovations and both individuals and families varied depending on gender, generation, social class, and individual biographies. Before I analyse this process, I will discuss the concept of the consumer revolution, which is useful for studying the transition from traditional to consumer societies.

\section{Consumer revolution}

Arjun Appadurai (1996) proposes three patterns of socially organised forms of consumption. The first pattern is interdiction, which is characteristic of small-scale, ritually oriented societies where what was called 'taboo' in earlier anthropological records regulates consumption for certain social categories, temporal contexts, and goods, combining cosmology and etiquette. The second pattern is sumptuary law, which was typical in medieval Europe. Since the fifteenth century in Western Europe, this law has transformed through the consumer revolution into the third pattern: fashion. Fashion regulates consumption in modern, capitalist, consumer societies. Changes in 
consumption can be linked to various sequences of particular factors, such as mass merchandising, mobile society, advertising and marketing, rising wages, class conflict, literacy, expert knowledge, and commoditised information. Developing the thoughts of Gabriel Tarde, Gilles Lipovetsky (1994) states that there are two essential forms of social bonds, which are based on imitation and imply different temporalities: custom and fashion. He differentiates between the ages of custom and the ages of fashion. The former 'are ruled by the prestige of antiquity and the imitation of ancestors', whereas the latter are 'dominated by the cult of novelty and the imitation of local and foreign models' (1994: 23). The shift from the ages of custom to the ages of fashion has been occurring in Western European society since the 1450s. In the ages of custom, consumption is regulated by interdiction or sumptuary law, whereas fashion is the primary driver in the ages of fashion.

Historians argue that the consumer revolution in Western countries began with the birth of capitalism and modernity (Braudel, 1981; McKendrick et al., 1982). The consumer revolution was the fruit of the rivalry between aristocracy and the bourgeoisie. The revolution burgeoned among the bourgeoisie during the second half of the eighteenth century in England as the other side of industrialisation (McKendrick et al., 1982). This period was characterised by increased demand for luxury goods (cloth and clothing, forks, pottery, furniture, coffee and tea, sugar): expenditure on industrial 
goods increased by approximately $370 \%$, and developments such as new marketing strategies, the birth of rapidly changing fashion, the leisure revolution, the development of the modern novel and a fiction-reading public, as well as the rise of romantic love occurred. Colin Campbell (1987) locates the mechanisms of the consumer revolution in the mentality of the bourgeoisie of that time, the same segment of society that was described by Max Weber in his study on Protestant ethics and the spirit of modern capitalism. As such, Campbell identifies two drivers of consumption: needs and desires. Fulfilling needs is the basis of existence in poorer societies; desires gain in importance as the standard of living improves. Before the consumer revolution, desires were the realm of aristocracy and took the form of traditional hedonism: pleasure consisted of a sensual experience gained through particular activities such as eating, drinking, sexual intercourse, or socialising. Campbell argues that modern hedonism is a contradiction of traditional hedonism and that modern hedonism developed because of the Romantic ethic alongside the Protestant ascetic attitude towards life and work. The Romantic and Protestant ethics are constituted by comparable emotional structure of personality, consisting of 'twin polarities: deferred versus instant gratification and the inhibited as opposed to uninhibited expression of emotions' (1987: 221). Modern hedonism relies on imagination and involves the replacement of actual stimuli with illusions and the construction of pleasurable environments in the mind. 
With the inception of the era of Fordism at the beginning of the twentieth century, the consumer revolution spread to all sections of American society along with the mass production of cars and household appliances (Cowan, 1976). Lending opportunities, high wages, and advertising accompanied by easy access to goods were all factors in the consumer revolution (Aldridge, 2003). In Western Europe, the working class began to adopt the American standard of living only after the Second World War. By the mid-1970s, new household consumption and new appliances, such as water heaters, stoves, washing machines, refrigerators, and sewing machines, became the national standard in Western Europe. In Eastern Europe, this standard was achieved by the mid-1980s (De Grazia, 2005). However, it was not only the timing of the adoption of domestic technologies that was different in socialistic countries, but the process by which the shift in patterns of consumption occurred.

\section{Consumer revolution in People's Poland: from custom to fashion}

To understand the course of the consumer revolution in People's Poland, I have analysed material collected during ethnographic fieldwork conducted between 2005 and 2007 and in 2012 using the life course approach (Hareven, 1982). Between 2005 and 2007, I conducted fieldwork on the experience of old age. The domestication of technologies was the primary topic discussed by the respondents in response to the 
question, 'Did the world change much during your lifetime, and how so?' From a total of 46 interviews, I selected 22: eleven narrative biographical interviews and eleven indepth interviews concerning changes during the life course and reactions to these changes with eleven respondents. In 2012, I conducted complementary fieldwork on the domestication of technologies. I conducted eleven interviews with seven interviewees, including narrative biographical interviews and in-depth interviews concerning changes during the life course with four respondents and combined interviews (a life narrative and an interview concerning changes during the life course, conducted during one meeting) with three respondents. Altogether, 33 interviews with eighteen respondents (five men and thirteen women) were used for the analysis. The participants were born between 1918 and 1942.

I chose Warsaw as the site for my fieldwork to reach a diversified group. The respondents came from Warsaw or migrated from villages and small towns from the former Russian and Austro-Hungarian partitions that had lower living standards before the Second World War. Polish lands were divided between Russia, Prussia, and the Austro-Hungarian Empire at the end of the eighteenth century, but these lands became reunited after the First World War. However, differences in economic development between the formerly partitioned lands continued to exist. The former Prussian partition was characterised by a capitalist market economy. The Russian partition was 
characterised by low industrialisation, primitive agricultural methods, goods exchange, and low living standards, namely, a lack of water infrastructure, sewage systems, and electricity and a predominance of wooden thatched huts (Tomaszewski, 1996).

In traditional rural communities, consumption was regulated as part of customary norms, 'which constitute extra-institutional but binding general normative system, involving public opinion and encouraging social control' (Kwaśniewicz, 1981: 90). Certain activities and goods were prohibited for particular social categories; thus, the pattern of consumption was interdiction (Appadurai, 1996). The dominant norm was the autonomy of male and female spheres of action. Male activities focused on preparing land for production, manufacturing tools, and engaging in public matters. Female activities included organising consumption, producing clothing, and raising children (Szynkiewicz, 1976). Acts of consumption of different goods were 'moments' (Warde, 2005) in male and female practices.

Individual narratives are framed by the wider context of collective memory (Halbwachs, 1925). The memories of respondents of different genders, family origins, generational affiliations, and life courses differed. The respondents belonged to different cultural generations: 1) the pre-war generation, which includes individuals who grew up in pre-war Poland; 2) the war generation, which includes individuals who spent their youth under occupation; 3 ) the generation of the Association of Polish Youth (ZMP), 
the name of which derives from a mass youth ideological-political organisation that indoctrinated young people in the post-war period; and 4) the thaw generation, which includes individuals who grew up during the so-called 'thaw', the period of reduced terror after the death of Stalin (Szatur-Jaworska, 2000). Representatives of the pre-war generation of upper-class origin experienced social degradation in People's Poland. They faced difficulties acquiring education and good jobs due to their higher-strata origins. Consequently, respondents of the pre-war generation of upper-class origin talked about the decline of morals after the war. The war generation and the ZMP generation mostly recalled the post-war progress; this was especially true for those of peasant origin who received education and improved their living standards (then referred to as 'social advancement'). Individuals of upper-class descent of the same generations discussed their rebellion against socialist values and reflected on their fascination with the West. The memories of homemaking women mostly focused on the increased comfort of living. The interviewees of the thaw generation, during whose youth the development of television occurred, discussed luxury consumer goods from the West.

I will draw on the memories of the aforementioned interviewee groups and categories to analyse two mechanisms of the shift in consumption patterns from regulation by interdiction towards fashion: the mechanism of collective usefulness in 
the two following subsections and the mechanism of modern hedonism in the third subsection. Within the first mechanism, one that has received insufficient attention in the literature, the emulation of new patterns of behaviour was supported by the spread of the idea of progress, where household innovations were perceived to be necessities to meet collective needs. Women played a leading role in the domestication of appliances, as in the West (Wajcman, 2000). Within the second mechanism, the adoption of new trends was stimulated by the media, which 'advertised' American practices and evoked desires.

\section{Post-war industrial revolution and the belief in progress versus adherence to custom}

The basic factor of the consumer revolution in Western countries, mass merchandising, was not present in People's Poland. The Polish economy became nationalised in 1946, and the number of privately owned retail shops dropped substantially, from 69,824 to 15,765 between 1949 and 1954 . This situation inhibited the growth of the home market as the network of state-owned retail points developed slowly (Central Statistical Office [CSO], 1956). ${ }^{1}$ Additionally, food rationing was in force after the war, followed by token allocations for selected professions until 1953. Due to the absence of privately owned manufacturers and competition and because of broad demand that exceeded supply, advertising and marketing did not develop. The 
socialist authorities invested in heavy industry, which developed rapidly until the beginning of the 1950s. Mass internal migrations occurred as youths from rural areas found employment in industry in the cities and began participating in the money economy. At the end of the 1940s, the inhabitants of villages constituted two-thirds of the population; in the 1960s, this number was less than half (Okólski, 2002). Mobile society, industrialisation, and the rising money economy were factors in the consumer revolution in post-war Poland.

The second industrial revolution in Poland was characterised by underinvestment in the consumer goods sector relative to that in Western countries (Davies, 2005). According to the Statistical Year Book for 1955 (CSO, 1956), the increase in consumption occurred among the former peasant class and was associated with their pre-war low standard of living. For example, the increasing prevalence of connection to the electrical grid, from $3.10 \%$ of villages connected to the grid in 1938 to $36.10 \%$ in 1954 (CSO, 1956), was viewed by the authorities as the indicator of progress. The consumption of new luxuries (such as sugar) doubled, and the population that consumed sugar, which now included peasants, also grew (CSO, 1956). Data concerning the consumption of textiles, clothes, furniture, and white goods are not included in the Statistical Year Book for 1955. However, the document provides data that shows significant growth in the production of textiles, such as cotton, wool and silk 
fabrics.

Industrialisation was accompanied by the elimination of illiteracy among the former peasant class (CSO, 1956) and the propaganda of progress, which was an integral element of the socialist ideology (Bauman, 1991). The new ideas were easily internalised by young people and pre-war peasant classes, for whom they constituted the first code of abstract thinking that explained post-war promotion in terms of class struggle and progress (Świda-Ziemba, 1998). The state-controlled publishing cooperative was established and published all journals in the Polish market. In 1950, the circulation of journals was two and a half times higher than it was before the war (Kłoskowska, 1964). By the 1950s, a small number of periodicals for women were released that targeted nearly every sector of the female public. The message was different from the message in women's magazines in Western Europe, where women were characterised as the managers of households full of modern appliances (De Grazia, 2005; Hand and Shove, 2004). Polish magazines for women in the 1950s showed disdain for household chores and family life, propagating the idea of women's employment in the job market (Sokół, 1998). Literacy and expert knowledge were factors that drove the consumer revolution in People's Poland. Instead of commoditised information, the state-controlled socialist propaganda of progress was the main factor that drove the consumer revolution. This factor contrasts distinctly with that of mass 
merchandising which, according to Appadurai (1996), was the driving factor of the consumer revolution in Western countries.

In narratives focused on the idea of progress, the upwardly mobile interviewees of peasant origin from the war and ZMP generations emphasised the contrast between their pre-war and current living standards. I call these narratives the narratives of progress. The narrative of Mr. Stanisław ${ }^{2}$ follows this pattern. Because he was of gentry origin, he did not experience social advancement. Before the war, however, he lived in a backward region of the former Russian partition. After the war, he became an engineer and witnessed considerable technological progress:

\footnotetext{
...in the village, there was even a simple hut [with a hearth, without a chimney] as a relic of old times... When it comes to washing oneself, I remember that when I went to school... and called on a friend on the way, he washed himself by taking water into a mug and then pouring it onto his hand and then onto his face. That way the people in the village did not have to carry so much water from the well... those village huts had no electricity. So connection to the electrical grid caused a radical change... (Mr. Stanisław)
}

The objects and practices mentioned above starkly contrast modern practices with respect to the effort that they require (a simple hut versus a centrally heated house, carrying water from the well versus washing oneself in the bathroom). The connection to the electrical grid constituted a central point in the narrative, both as an outcome of 
the official indoctrination and as a reasonable observation given that the availability of household electricity facilitated the adoption of additional innovations.

Technology introduced enormous changes into people's lives, making life easier for inhabitants of cities and villages... And, undoubtedly, we have to recognise this as progress when we compare living conditions then and now. (Mr. Stanisław)

The narratives of progress were accompanied by the emotion of excitement, which was present in a raised tone of voice and emphatic wording, such as 'radical', 'undoubted progress', and 'enormous'. Interpretations of the consumption motives in consumer societies indicate that the excitement is related to new goods that deliver new experiences to individuals (Illouz, 2009). However, the narratives of the respondents seem to evoke excitement about the possibility of fulfilling collective needs. The values at the base of the narratives of progress are collective and rational.

Although technology evoked excitement in Mr. Stanisław, the resultant reshuffling of the gender division of duties raised anxiety:

...with the popularisation of reading and writing and using technical advancements also in the households, women had more time on their hands to devote to work...to professional duties in various factories and offices alongside men. I think that...the conditions of raising children are better when the mother is unoccupied with professional matters and can take care of children for the 
whole day...It would be a handier situation if men could...earn enough to feed everyone in the household and women could take care of children.... (Mr. Stanisław)

Mr. Stanisław's wife acquired an education and worked professionally. His mother, who was living with them, cared for their children, so Mr. Stanisław agreed that his wife would work. According to the socialist ideas of progress, women were expected to participate in the collective division of labour outside the private sphere of their homes. The need for women to work also resulted from the impossibility of feeding the family on one salary. The duties of raising children and managing the household were often taken on by grandmothers (Szpakowska, 2003). This model differed from that in Western countries, where a single salary was sufficient to provide for the family and where married women managed the household in the 1950s and 1960s.

The introduction of 'progress' into the sphere of the gender division of duties affected the customary norm of the autonomy of male and female spheres of action. Echoes of adherence to custom were strongest in the narratives of people from the prewar generation, who were from the higher strata of society and were declassed in People's Poland. Ms. Barbara's husband refused to become a member of the Party ${ }^{3}$ and consequently lost a number of qualified jobs and had to resort to simple labour. In line with the customary gender labour division, Ms. Barbara did not take on paid work and had to perform physical work in the home because her family could not afford to hire a 
maid. Faced with the onslaught of new experiences, she discussed, with dismay and indignation, how the customary norms no longer regulated behaviour:

\author{
I am terrified by the permissiveness, lack of faith... these days, apologies for this explicit \\ language, women go and open men's flies, because that's what I can see in the pictures. \\ These gestures, dancing, all of this is sexy, sexy, sexy. In the past, a woman was somebody; \\ he had to pray to her. Like my grandma said, 'In the past, he was courting, assisting, and it \\ was then that they were engaged and then there was a wedding'. The women have liberated \\ themselves! They want to have power now! And the children, they are left in crèches, \\ kindergartens; it's not the same as being taken care of by one's mother. (Ms. Barbara)
}

The norm of the autonomy of male and female spheres of action was no longer as binding for individuals who grew up after the war, but it still strongly influenced the process of fashion formation.

\title{
Technology use practices: fashion in negotiation with custom
}

The majority of women who were responsible for household chores discussed household implements differently than men did (Wajcman, 2000) by referring to particular instances of using the facilities, not the general convenience resulting from them. Ms. Antonina from the ZMP generation, an office clerk from a bourgeois family, began her narrative by stating that the increase in comfort over the course of her life was 
so enormous that people accustomed to today's standard of living would not have coped in the post-war period.

You know, even such inventions helping one to live; when I had small children, I had to boil the nappies in a cauldron on a gas stove and had to wash them using a washboard in the bath tub. I can't imagine, for example, Piotrek and Paweł [grandsons], not even my daughter doing this. (Ms. Antonina)

The most substantial change that the women cited was the change in doing laundry due to the introduction of washing machines. I call this change the 'laundry revolution' after Victoria de Grazia (2005). While discussing laundry, the women emphasised the elimination of physical effort owing to the introduction of washing machines. Soon after the war, families often consisted of women only (Szpakowska, 2003), and housework was customarily performed by women as a group.

...you would carry water from the corner of the street in a bucket to do some laundry..., so you had to burn some fuel in the stove and boil some water in a cauldron. Then, in a wash tub with a washboard, you washed by hand... bedding from five, six beds; to wash it all and rinse, you had to carry a lot of water. Usually, you didn't do the laundry in the winter that much. We were doing it in the autumn. There wasn't that much linen; we only had two changes of bedding. I know that you would collect it, and if you changed the sheets for Christmas, then the next time would be for the 2nd February for Candlemas. When the weather was good in the autumn, then in mid-October, and then [after winter], you would change them as often as every month. (Ms. Jolanta) 
The narrative of Ms. Jolanta, a native Varsovian from the thaw generation who was raised with her two sisters by her grandma and mother, conveys the tremendous effort required to do laundry. Objects different from those used today mediated doing laundry, such as the well, bucket, cauldron, wash tub, and washboard. The incorporated practices were also different: carrying buckets of water, boiling water in a cauldron, and washing, rinsing, wringing, and starching laundry. The temporal cycles of washing were dictated by both nature (laundry was not done in the winter) and culture (doing laundry was inscribed in the Church liturgical cycle, for Christmas and Candlemas). The practices of everyday life were regulated by customary norms, which were the guardians of a religious view of the world. The 'Frania' upright rotary washing machine appeared in the 1950s:

We had the first 'Frania' when I was 14, so it must have been...1954.... But my grandma liked it when the bedding from all the beds was changed at the same time, so the laundry was in this order: cover, eiderdown, bed sheet, and the pillow, which made the Frania fully loaded.... So that would take a few days. So my grandma was annoyed and didn't like it and was saying that the laundry was to be done on a Saturday by noon, and she preferred to do it all at the same time and to hang it out to dry outside... rinsing, starching, that was done by hand, and washing of more soiled items was done by the Frania. But she would take the pillows to the wash tub and wash them there by hand. But it was still easier, as before everything had to be done by hand. (Ms. Jolanta) 
The laundry practices in this family were partly changed by the Frania. Only the most soiled items were washed in the Frania, and the rest was still hand washed. The reason for this resistance was the steadiness of Ms. Jolanta's grandma's habits, which was characteristic of the ages of custom (Lipovetsky, 1994).

Małgorzata Szpakowska (2003) analyses the letters sent to women's magazines by readers in the 1960s, who discussed the changes to their households introduced by the Frania. After the mass migrations from villages to cities, the nuclear family gained in importance as a collaborative unit. In the 1950s and 1960s, the washing was done in the Frania, but other actions, such as rinsing, wringing, and starching, were still done by hand. Because of the physical effort these actions required, they were performed by the whole family, including men. During this period, doing laundry fulfilled a prosocial function by integrating the nuclear family (Szpakowska, 2003) and by taking the family out of the 'jurisdiction' of custom.

Although the functional features of the Frania required men in nuclear families to participate in the process of doing laundry, the customary norms of the autonomy of male and female spheres of action hindered changes in everyday practices. Ms. Antonina, a clerk from a bourgeois family, made an interesting remark about these changes: 
I come to my sister one day..., and the door is opened by my brother-in-law, who is hiding behind the door. I say, 'Adaś, is anything the matter?' 'Wait, wait!' I can see that behind the doors, he is trying to take off an apron, as my sister has just managed somehow to get him to do the washing. It was humiliating for men, doing anything in the house. My father, as far as I remember, was always dealing with his own business. I can't remember him ever making tea for my mum, for example; it was always my mum who made it ready for him. Some other things, like hammering in a nail, hanging something, were, naturally, male tasks.... My husband was helping me when we moved here, when the kids were little, until my mother-in-law moved in. When she moved in, whenever I said to him, 'Maybe you could peel the potatoes, or take the rubbish out', whatever, he would say, 'Three women in the house, I'm not going to do anything!' That was 12-year old Kasia [daughter], a seventy-something old woman and me. (Ms. Antonina)

When young married couples lived by themselves, the wives could not manage to deal with all customarily female activities, and the husbands helped. Due to the introduction of new technologies to households, the customarily female activities required new skills. Technologies, as the carriers of a wider social order (Dant, 2007), suggested new behaviour through the functionality inscribed in them. Practices consist of materials that mediate practices, skills (the embodiment of practices), and shared meanings of practices (Hand and Shove, 2007). In spite of the changes in materials and skills involved in new practices of household work, the meanings did not change. These practices were still perceived as female activities. Husbands did not publicly admit to performing them because this behaviour broke customary norms and was considered 
embarrassing. When an opportunity arose, Ms. Antonina's husband withdrew from helping, especially because he would have to perform activities prohibited by custom in the presence of his mother.

The introduction of automatic washing machines in the 1970s and 1980s significantly altered customarily female practices. Female respondents regarded these washing machines as luxuries rather than as necessities because of the full automation of washing. Ms. Agnieszka's working-class family welcomed the automatic washing machine with delight.

\footnotetext{
For example, the Frania and the automatic washing machine, it's a big difference. I turn on the washing machine, and it washes on its own. I remember when we bought the first washing machine, we were sitting, the three of us, in the kitchen, and we were watching this washing machine like a TV programme. It was a novelty; you just turn it on, it washes on its own, you just take the clothes out, and this is comfort. (Ms. Agnieszka)
}

Because all phases of laundry were performed automatically by the machine, family collaboration in laundry became superfluous. The introduction of fully automated appliances in the households replaced the need for physical labour at home. According to Ms. Antonina, due to the full automation of household work, men started to participate in it without embarrassment. 
Nowadays men help more. (...) there is a lot of improvements: take the laundry, for example. A man turns on the washing machine and it washes on its own; a man opens a washing machine and takes everything out. Well, it doesn't require any particular philosophy. (Ms. Antonina)

The new materials (fully automated appliances) and new skills (no need for physical labour) involved in new practices of household work contributed to the change in the meanings of these practices. Ms. Antonina stopped perceiving them as customarily female activities. Instead, everyday practices in her family became flexible, and members of the family became open to the information inscribed in the functionality of the appliances. This change can be interpreted as a shift in socially organised patterns of consumption from regulation by interdiction towards fashion, demonstrating how the adoption of domestic technologies contributed to the consumer revolution in Poland.

\section{Western luxuries and modern hedonism}

Despite the Iron Curtain, the Poles were aware that the standard of living in Western countries was higher than that in Poland because of gifts from the United Nations Relief and Rehabilitation Administration (UNRRA) or from families living abroad. Western clothes were distributed as part of an informal economy. Coca-Cola and chewing gum were symbols of the American standard of life associated with luxury (Kurz, 2008). The most popular weekly magazine, 'Przekrój', 'smuggled' information 
about innovations from the West. At the end of the 1940s, when hardly anyone in Poland could afford a car, the magazine published a series of articles called 'The magic of four wheels', disseminating dreams and knowledge about cars (Jaworska, 2008). The content published by the magazine fulfilled the role of an advertisement, which was a factor in the consumer revolution in Western countries.

The origins of modern hedonism may be traced to the rebellion against socialist values among the respondents from the ZMP generation of upper-class origin. Mr. Janusz graduated from the Warsaw University of Technology. After the war, there was high demand for people with technical education, and the Warsaw University of Technology was an enclave for people of 'unsuitable' social origins. Technical specialists were part of the leisure class of People's Poland, which provided them with high earnings and considerable social support. Mr. Janusz had a housekeeper. Neither women nor men from his social circle had to do household chores; therefore, they did not mention the changes introduced by household appliances in their narratives. They dined outside the home every evening, partied every weekend, participated in cultural events every week, and spent every holiday at seaside or mountain resorts.

We were partying a lot. In the 1940 s, 50 s, and 60 s, we used to go to various parties, balls, dances..., so the time was passing pleasantly. (Mr. Janusz) 
Mr. Janusz was against the socialistic system. From his early youth, he pursued a 'consumer' lifestyle, which he perceived as a sort of rebellion because the socialist propaganda associated consumerism with the West:

I could see what the communists were mocking. Because they were mocking these socalled troublemakers who were wearing fashionable clothes, such as colourful socks...I wouldn't wear black socks, they had to be colourful...Yes, we did pay attention to appearance. (Mr. Janusz)

The values created by these professional and social circles were rooted in those of the pre-war upper classes from which the group members derived. In their case, consumption had political significance. Just as cigarette smoking by women was an expression of rebellion against the oppression of the patriarchal culture in the 1920s (Illouz, 2009), the rebellion against the communist oppression and the wish to live in a democratic country became joined with the desire to mimic Western consumer practices.

The attitude towards consumption in the Soviet bloc was changed by the 1959 Nixon-Khrushchev Kitchen Debate, in which Khrushchev vowed to outperform America in the realm of household appliances. In Poland, this promise clashed with the aversion of the Party leader, Wiesław Gomułka, to 'worldly possessions' (Kurz, 2008). In the 1960s, the function of advertising the American standard of living was assumed 
by television, which, in this period, served entertainment purposes and broadcast numerous American films (Pleskot, 2007). At the beginning of the 1960s, primarily young city dwellers and the intelligentsia watched television. By the end of the 1960s, viewership became universal, with the number of television sets growing to 4 million by 1969 (Kurz, 2008). However, the actual audience was larger because people watched television in groups with their neighbours and families. Poles' consumer dreams were not fulfilled until the 1970s, when the new Party leader, Edward Gierek, took out loans from Western countries and imported Western technologies to produce consumer goods (Davies, 2005). The accessibility of white goods, cars, and clothes increased; for example, the supply of refrigerators increased by $115 \%$ and the supply of television sets increased by 44\% (Haranne and Siciński, 1987). I argue that modern hedonism already ruled consumption in the 1960s, when the Poles dreamed of living like the Americans, rather than in the 1970s, when consumer goods became accessible.

In the latter half of the 1950 s, the respondents watched television at their family's or the neighbours' homes. In the 1960s, the majority of the respondents bought black and white television sets. 'Novelties' were the primary topic discussed by the representatives of the thaw generation, who grew up in the post-Stalinist era, when consumption in the Soviet bloc increased in importance and when the American daily life practices that were projected on television screens stimulated consumer appetites. 
Novelties were technological innovations that were considered luxuries by the respondents from the thaw generation, such as phones, televisions, and cars. These goods did not include household appliances because such appliances were perceived by the majority of the respondents as necessities; only the automatic washing machine, because of the complete reduction of physical effort, was considered a luxury good.

Ms. Małgorzata came from a middle-class intelligentsia family in Warsaw and belonged to the thaw generation. She earned higher technical education and was interested in technology. I will discuss the emergence of modern hedonism by using the example of her use of a car:

For me, the car was also a luxury, a great luxury, a great dream.... I passed my driving exam in the 1960 s... both for a motorcycle and a car.... I had various friends with cars, so they had to put up with a lot because I was begging them to give me a chance to drive.... Back then you couldn’t just go...choose a colour, options and buy a car.... You needed tokens [from one's workplace]. I got them then [in 1973]...I got a token for the little one [Fiat 126p].... Mine was very poor. They constantly had to push me. It had a problem with the starter. So in the end, I sold this one, and we had a big Fiat [Fiat 125p]. I was annoyed because my husband with a briefcase was driving the car while I, the housewife, carrying heavy bags, had to walk. So I said, 'Oh no, that's it!' and I bought myself the little one again. (Ms. Małgorzata) 
The dream of a car derived from American road movies, in which driving a car was associated with freedom. Ms. Małgorzata and her husband realised this dream with the help of a substitute: a motorcycle. One summer, they rode motorcycles with a group of friends to a wild part of the Polish Baltic coast. American practices with the 'moments' of consuming substitutes were characteristic of consumption in People's Poland. Ms. Małgorzata anticipated driving a car with excitement. The emotion that she associated with driving a car was a sense of independence, being able to go everywhere she wanted, and prestige, being able to engage in the same practices as her husband. Her car often broke down, and Ms. Małgorzata was thus dependent on the help of other people. When the object being used is resistant (its behaviour cannot be predicted) (Latour, 2005), it is difficult to talk about boredom, which, according to theories of consumption, replaces excitement after a period of use and leads to excitement about novelties that the individual does not yet possess (Illouz, 2009). In this case, the pattern was different. Instead of frustration caused by boredom, Ms. Małgorzata experienced frustration with the malfunctioning car, which led her to wish for a new model. When the Fiat 126p turned out to be unreliable, Ms. Małgorzata bought another one. Ms. Małgorzata's experience of imagining a new practice for a few years in the absence of a real stimulus, her subsequent frustration with the desired object, and the consequent transfer of her 
excitement onto a new object indicates that a pleasant environment was being created in her imagination, which is characteristic of the mechanism of modern hedonism.

Ms. Władysława, a native Varsovian from the thaw generation with a primary school education who worked as a quality controller in the food industry, looked upon household appliances as luxury goods. Among these luxury goods, she enumerated a mincer, a sewing machine, and a floor polisher. For her, these items were status indicators; she emphasised that she was the first to have them among her family and neighbours. The representatives of the working class considered modern household appliances a basic indicator of status (Pawełczyńska and Tarkowska, 1987). The aforementioned competition concerned not only the number of appliances in one's possession but also the appearance of the house, including order and cleanliness: ...in my mum's family, everybody was jealous that...I was so good with everything.... People came up to me asking how I did the floors, what do I varnish them with, what do I wax them with. And I don't know anything about varnishes. You had to use wire wool on your knees, wax, scrub. When my colleagues came to visit me, they said later that even the [government] minister didn't live the way Władźka did. (Ms. Władysława)

Imagining herself as a perfect housewife and receiving envy from others appeared to be a source of pleasure for Ms. Władysława, in line with the mechanism of modern hedonism. She spent her free time performing household chores (such as her annual painting of window frames instead of holiday-making). Research indicates that with the 
introduction of household appliances, women spent an increasing amount of time on household chores (Bittman, Rice and Wajcman, 2004; Cowan, 1976; Lury, 2011; Vanek, 1974). In many countries, working-class housewives were mimicking the American model, in which women acted as household managers and in which appliances reflected status symbols (de Grazia, 2005; Pérez, 2012). The working-class women of the thaw generation in People's Poland likely also internalised the American housewife model.

\section{Conclusion}

The wider context of changes in the patterns governing consumption seems to be a fruitful perspective for analysing the domestication of technologies. The present analysis demonstrates how existing patterns of consumption influenced the adoption of domestic technologies and then how the practices of using domestic technologies altered patterns of consumption.

Researchers of modern consumption note that the mechanism of 'fulfilling desires' rather than the mechanism of 'satisfying needs' drives modern consumption (Appadurai, 1996; Campbell, 1987; Illouz, 2009). Research on the emergence of fashion in People's Poland shows that fashion may develop through both mechanisms: satisfying needs and fulfilling desires. In the case of the former, the mechanism of 
collective usefulness, household appliances were adopted as necessities that helped people fulfil their needs, in line with the socialist state's propaganda of progress during the post-war period. In the process of the domestication of technologies customary female activities were being transformed into flexible everyday practices with 'moments' during which household appliances were used. This analysis therefore challenges conventional theoretical understandings of the consumer revolution highlighting two hereto neglected factors essential to understanding how it unfolded in Poland: the propaganda of progress and the adoption of domestic technologies. Both of these factors contributed to increasing flexibility of practices characteristic of fashion, which governs consumption through social emulation.

\section{Acknowledgments}

The author thanks the anonymous reviewers and the editor for their insightful input to an earlier version of this article, as well as Elz_ bieta Tarkowska, Miroslawa Marody, Iwona Zielin' ska and Piotr Binder.

\section{Funding}

This work was supported by the Marie Curie Early Stage Research Training Fellowship, Sixth Framework Programme (MEST-CT-2005-020702); and the Ministry of Science and Higher Education of Poland (N116 004 32/0387).

\section{Notes}

1. According to historians, the data in the Statistical Yearbook for 1955 are not falsified, but the information may have been presented selectively. 
2. The names of the interviewees have been changed. The form 'Ms./Mr. Name' is used because it is a common way of addressing or discussing someone in private situations in Poland.

3. People's Poland was governed by the Polish United Workers' Party, or the Party.

\section{References}

Aldridge A (2003) Consumption. Cambridge: Polity Press.

Appadurai A (1996) Modernity at large. Cultural Dimensions of Globalization. Minneapolis, MN: University of Minnesota Press.

Bauman Z (1991) Modernity and Ambivalence. Ithaca, N.Y.: Cornell University Press.

Bittman M, Rice JM and Wajcman J (2004) Appliances and their impact: the ownership of domestic technology and time spent on household work. The British Journal of Sociology 55(3): 401-423.

Braudel F (1981-84) Civilization and Capitalism, 15th-18th Centuries (trans. S Reynolds). New York: Harper and Row.

Campbell C (1987) The Romantic Ethic and the Spirit of Modern Consumerism. Oxford: Blackwell Publishers.

Central Statistical Office (1956) Statistical Yearbook 1955 (Rocznik Statystyczny 1955). Warsaw.

Cowan RS (1976) The „Industrial Revolution” in the Home: Household Technology and Social Change in the 20th Century. Technology and Culture 17(1): 1-23.

Dant T (2007) The 'pragmatics' of material interaction. Journal of Consumer Culture 8(1): 11-33.

Davies N (2005) God's Playground. A History of Poland Vol. II. Oxford: Oxford University Press.

De Grazia V (2005) Irresistible Empire: America's Advance Through Twentieth-century Europe. Cambridge, MA: Harvard University Press. 
Giza-Poleszczuk A (2002) Rodzina i system społeczny [Family and social system]. In: Marody M (ed.) Wymiary życia społecznego. Polska na przełomie XX i XXI wieku (Dimensions of social life. Poland at the turn of the 20th and 21st centuries). Warsaw: Scholar, pp.272-301.

Halbwachs M (1925) Les cadres sociaux de la mémoire. Paris: Librairie Félix Alcan.

Hand M and Shove E (2004) Orchestrating Concepts: Kitchen Dynamics and Regime Change in Good Housekeeping and Ideal Home, 1922-2002. Home Cultures 1(3): 235-256.

Hand M and Shove E (2007) Condensing Practices: Ways of living with a freezer. Journal of Consumer Culture 7(1): 79-104.

Haranne M and Siciński A (1987) Changes of Life Styles in Finland and Poland. In: Roos JP and Siciński A (eds) Ways of Life in Finland and Poland. Comparative Studies on Urban Populations. Aldershot: Avebury, pp.12-35.

Hareven T (1982) The life course and ageing in historical perspective. In: Hareven T and Adams KJ (eds) Ageing and life course transitions: an interdisciplinary perspective. London: Tavistock Publications, pp.1-26.

Illouz E (2009) Emotions, Imagination and Consumpton. A new research agenda. Journal of Consumer Culture 9(3): 377-413.

Jaworska J (2008) Cywilizacja "Przekroju”. Misja obyczajowa w magazynie ilustrowanym ("Przekrój" civilisation. Moral mission in an illustrated magazine). Warsaw: Wydawnictwa Uniwersytetu Warszawskiego.

Kłoskowska A (1964) Kultura masowa. Krytyka i obrona (Mass culture. Criticism and defence). Warsaw: PWN.

Kornai J (1992) The Socialist System. The Political Economy of Communism. Princeton: Princeton University Press. 
Kurz I (2008) Konsumpcja: “coca-cola to jest to!” [Consumption: Coca-Cola. This is it!]. In: Szpakowska M (ed.) Obyczaje polskie. Wiek XX w krótkich hastach (Polish customs. The 20th century in slogans). Warsaw: W.A.B., pp.145-157.

Kwaśniewicz K (1981) Zwyczaje i obrzędy rodzinne [Customs and family rituals]. In: Biernacka M, Frankowska M and Paprocka W (eds) Etnografia Polski. Przemiany kultury ludowej (Ethnography of Poland. Transformations of folk culture) Vol. II. Wrocław: Ossolineum, pp.88-126. Latour B (2005) Reassembling the social: an introduction to Actor-network theory. Oxford: Oxford University Press.

Lipovetsky G (1994) The Empire of Fashion. Dressing Modern Democracy. Princeton, NJ: Princeton University Press.

Lury C (2011) Consumer Culture. Cambridge: Polity Press.

McKendrick N, Brewer J and Plumb JH (1982) The Birth of a Consumer Society: The Commercialization of Eighteenth-Century England. Bloomington, IN: Indiana University Press.

Okólski M (2002) Przemiany ludnościowe w Polsce w perspektywie minionego stulecia [Demographic changes in Poland in the twentieth century]. In: Marody M (ed.), Wymiary zycia społecznego. Polska na przetomie XX $i$ XXI wieku (Dimensions of social life. Poland at the turn of the 20th and 21st centuries). Warsaw: Scholar, pp.26-68.

Pawełczyńska A and Tarkowska E (1987) Life Styles of Individuals and Families in Polish Cities. In: Roos JP and Siciński A (eds) Ways of Life in Finland and Poland. Comparative Studies on Urban Populations. Aldershot: Avebury, pp.87-110.

Pérez I (2012) Comfort for the people and liberation for the housewife: Gender, consumption and refrigerators in Argentina (1930-60). Journal of Consumer Culture 12(2): 156-174.

Pleskot P (2007) Wielki mały ekran. Telewizja a codzienność Polaków w latach sześćdziesiatych (Big 
small screen. Television and the everyday life of Poles in the 1960s.). Warsaw: Trio.

Schatzki T (2001) Introduction: practice theory. In: Schatzki T, Knorr-Cetina K and von Savigny E (eds), The practice turn in contemporary theory. London: Routledge, pp.10-23.

Silverstone R (1993) Time, Information and Communication Technologies and the Household. Time \& Society 2(3): 283-311.

Sokół Z (1998) Prasa kobieca w Polsce w latach 1945-1995 (Women's magazines in Poland between 1945 and 1995). Rzeszów: Wydawnictwo Wyższej Szkoły Pedagogicznej w Rzeszowie.

Szatur-Jaworska B (2000) Ludzie starzy i starość w polityce społecznej (The elderly and the old age in social policy). Warsaw: Instytut Polityki Społecznej UW.

Szpakowska M (2003) Chcieć i mieć. Samowiedza obyczajowa w Polsce czasu przemian (To want and to have. Consciousness in Poland in the age of transformation). Warsaw: Wydawnictwo W.A.B.

Szpakowska M (ed.) (2008) Obyczaje polskie. Wiek XXw krótkich hasłach (Polish customs. The 20th century in slogans). Warsaw: Wydawnictwo W.A.B.

Szynkiewicz S (1976) Rodzina. Elementy systemu pokrewieństwa [Family. Elements of the kinship system]. In: Biernacka M, Frankowska M and Paprocka W (eds) Etnografia Polski. Przemiany kultury ludowej (Etnography of Poland. Transformations offolk culture) Vol. I. Wrocław: Ossolineum, pp.477-501.

Świda-Ziemba H (1998) "My nowe życie tworzymy i nowy ład" ["We are creating a new life and new order”]. In: Siciński A (ed.) Do i od socjalizmu (Towards and away from socialism). Warsaw: PWN, pp.91-109.

Tomaszewski J (1996) Dwadzieścia lat niepodległości [Twenty years of independence]. In: Mączak A (ed.) Od plemion do Rzeczypospolitej. Naród, państwo, terytorium w dziejach Polski (From tribes to the Polish Commonwealth. The nation, country and territory in the history of Poland). Warsaw: 
Książka i Wiedza, pp.205-248.

Vanek J (1974) Time Spent in Housework. Scientific American 231(5): 116-120.

Wajcman J (2000) Reflections on Gender and Technology Studies: In What State is the Art? Social Studies of Science 30(3): 447-464.

Warde A (2005) Consumption and Theories of Practice. Journal of Consumer Culture 5(2): 131-153.

Zalewska J (2011) Nowe przedmioty a przemiany praktyk społecznych w doświadczeniu ludzi starych

[New material objects and the change of social practices during the life course of the elderly]. In:

Mucha J and Krzyżowski J (eds) Ku socjologii starości. Starzenie się w biegu życia jednostki

(Towards the sociology of old age. Ageing in the life course of individuals). Cracow: AGH, pp.201-226. 